\title{
API Manufacture
}

National Cancer Institute

\section{Source}

National Cancer Institute. API Manufacture. NCI Thesaurus. Code C82401.

The act of producing active pharmaceutical ing redients from raw materials. 